\title{
Role of Kisspeptin in Female Infertility
}

\author{
Bhuiyan MRI ${ }^{1}$, Khaliduzzaman $\mathrm{SM}^{2}$, Priti $\mathrm{KN}^{3}$
}

\begin{abstract}
Background: Kiss1, a noble G protein coupled receptor designated as GPR54, was first identified in rat brain in 1999 and orthologue gene identified in human in 2001 the original niche for the function of kisspeptin was restricted to cancer biology for their ability to suppress tumor metastasis. However, kisspeptin has recently emerged as a key player in the field of reproductive endocrinology. Method: A systematic literature review was done by using PUBMED. Though there is lack of human data, used animal data also hold translational potential for human. Results: Inactivating mutation of GPR54 gene is linked with absence of puberty onset and idiopathic hypogonadotrophic hypogonadism. Furthermore, recent studies support critical role of kisspeptin/GPR54 system on regulation of GnRH neurons, involvement of puberty onset and gonadal steroid feedback. Conclusion: This review will briefly discuss on cellular and molecular level of kisspeptin, their potential effects on human and clinical application of kisspeptin on human reproductive disorder.
\end{abstract}

\section{Introduction}

Procreation is an indispensable part of every species. To initiate and control reproduction, coordination of neuronal networks play complex role and finally make a common pathway, which is well known as Hypothalamic Pituitary Gonadal (HPG) axis that synthesize gonadotrophic releasing hormone. Since its discovery, adequate pulsatile hypothalamic gonadotrophic releasing hormone (GnRH) secretion has been considered as key element for maintaining reproductive function. ${ }^{1-4}$ During puberty, hypothalamus start synthesis and release of GnRH, which acts on anterior pituitary to secrete $\mathrm{FSH}$ and $\mathrm{LH}$, as a result gonads begin to produce sex steroid and peptide hormone. ${ }^{5-7}$

Only a decade ago in 2003, discovery of kisspeptin and its role on regulation of the HPG axis, revolutionized our current understanding on control of human reproduction. ${ }^{8}$ It is believed that, kisspeptin and functional neural network KNDY (kisspeptin / neurokinin / dynorphin) system modulate GnRH pulse. Therefore, Kisspeptin is considered as a key regulator of gonadotropin secretion and responsible for many physiological phenomenons. Moreover, manipulation of KNDY neural network and regulation of LH pulse, subsequently control of gonadal hormonal secretion may open a new horizon in treatment of infertility. Recently reproductive scientists are working for future application of KNDY system by increasing $\mathrm{LH}$ pulse, like wise hypothalamic amenorrhea, hypogondotrophic hypogonadism or reduce $\mathrm{LH}$ secretion, such as in polycystic ovary syndrome. ${ }^{9}$ 


\section{REVIEW ARTICLE}

In this review, briefly discussed on cellular and molecular level biology of kisspeptin and its potential effect on human, more precisely on female reproduction, and how future clinical application of kisspeptin may resolve neural reproductive disorder. A systematic literature review was done by using PUBMED. Though there is lack of human data, used animal data also hold translational potential for human.

\section{Discovery of Kiss1 Gene and Receptor}

Kiss1, a noble G protein coupled receptor designated as GPR54, was first identified in rat brain in 1999. ${ }^{10}$ This newly identified molecule catalogued as a suppressor of metastasis in melanoma cell line, therefore it is widely known as metastin. Hershey, (PA, USA) which was famous for Hershey kisses chocolate and birthplace of kiss I gene, also named as kiss after this exclusive sweets. However, 2 years later, in 2001, orthologue gene AXOR12 and hOT7T175 identified in human and termed as KISSIR. ${ }^{10-12}$ Three independent research groups explore endogenous ligand of GPCR named as GPR54 ${ }^{13}$, AXOR12 ${ }^{11}, H O T 7 T 175^{12}$ by using different model, CHO K1 $1^{13}$, HEK $293^{11}$ and B16-B26 ${ }^{12}$ consecutively. Therefore, international pharmacology association displaced metastin to kisspeptin considering structural similarities and origin of kiss1 derivative peptides.

\section{Biology of Kisspeptin}

Kisspeptin, a noble neuromodulator, which is peptide in nature and encoded by the kiss 1 gene that activate $G$ protein coupled receptor and upstream GnRH secretion. Kisspeptins are generated from a single precursor through various proteolytic processing. ${ }^{14}$ In human, kisspeptin precursor encodes 145 amino acid including a 54 amino acid region, named as kisspeptin 54 (formerly termed as metastin). 12,15 This segment can be further divided into low molecular weight forms which are termed as KP 54, KP13, KP 10 for 14, and 13 and 10 amino acid peptide respectively. In addition, all peptide fragment share c terminal sequence of kisspeptin 54 , which is the characteristics feature of RF amide group of peptide, collectively known as kisspeptin. ${ }^{12}$ Kiss 1R, upon binding its ligand kisspeptin activates phospholipase $\mathrm{C}$ and convert secondary intracellular messengers, inositol 1,4, 5 triphosphate (IP3) and diacyl glycerol, that induce calcium release and finally activation of protein kinase $\mathrm{C}$ to proceed kisspeptins function. ${ }^{11,16-17}$

\section{Distribution of Kisspeptin}

In 2001, different independent study group isolated kiss1 mRNA from placenta, spinal cord, pancreas, and pituitary gland by using reverse transcriptase polymerase chain reaction. ${ }^{11-13}$ In addition, northern blotting test has revealed kiss1 and GPR54 genes in peripheral area, such as heart, liver, kidney, placenta and Immune Reactivity (IR) found in different areas of the brain. ${ }^{18,19}$ Thus in 2005, specific population of kiss1 neuron has been recognized in hypothalamus. ${ }^{11-12}$ Infundibulum as source of kiss1 neuron has been isolated from autopsy samples of premenopausal and post-menopausal women. ${ }^{20}$ Furthermore another study done in 2010 including both male and female autopsy sample support the location of most dense Kisspeptin neuron area as infundibulum and 
second most dense as pre-optic area. ${ }^{21}$ As highlighted above, Kisspeptin neuron has been detected in the Infundibular / Arcuate Nucleus in all species. However, availability of Kisspeptin neuron in rostral pre-optic area varies from species to species. ${ }^{21-25}$ For example, in rat model Kisspeptin is located in rostral periventricular region of the third ventricle of its brain whereas, it is absent in human brain. ${ }^{26-27}$ Only infundibulum in human, homologous to arcuate in rodent express all three KNDY neuron. ${ }^{36}$

\section{Physiological Action of KNDY Neuron}

GnRH pulse is mainly mediated by gonadal steroid, (steroid sensitive receptor). ${ }^{30}$ In a study by Goodman et al revealed that Kisspeptin / Neurokinin / Dynorphin are in same functional neuronal network, collectively known as KNDY network which is steroid sensitive and play as a crucial regulator for GnRH pulse. ${ }^{29}$ In a schematic overview published by Skoroupskate et al 2014 to correlate KNDY-GnRH pathway and sex steroid feedback system ${ }^{9}$ which is adapted in this article. (Fig:1) It was not until 2003, that GPR54 mutation in men was identified to be associated factor for hypogonadotrophic hypogonadism and subsequently absent/delayed puberty, made a revolutionary understanding in role of Kisspeptin and KNDY neuron GnRH pulse. Furthermore, subsequent research has revealed that KNDY subpopulation in various species range from rodent to human play a key role in $\mathrm{GnRH}$ secretion by controlling neuro activity of KNDY cells. ${ }^{30-32}$ These reciprocally inter connected KNDY cells are very sensitive to steroid and act by direct contact with GnRH cell bodies and neuro secretory terminal (in human) on to the median eminence (in rodent, sheep \& monkey). 22,23,25,33 In 2009, Navarro et al discovered that $\mathrm{LH}$ secretion was inhibited by dynorphin and neurokinin $\mathrm{B}$, which act auto synaptically on pulsatile release of Kisspeptin and drive pulsatile release of GnRH and $\mathrm{LH}^{34}$

\section{Role of steroid on Kisspeptin}

Studies with human and various animal models suggest that pulsatile GnRH secretion followed by LH secretions is controlled by steroid feedback. ${ }^{35}$ However, GnRH neuron located in hypothalamus are devoid of estrogen receptor that suggests another group of neuron is essential to convey message of ovulation induction to GnRH neuron. ${ }^{9}$ After discovery of physiological role of KNDY it is suggested as <missing link> of gonadal steroid feedback.

Various animal data collection suggests that estrogen derived negative feedback has been mediated by Kisspeptin neuron and neurokinin B of arcuate nucleus. In ovariectomised animal model (rodents, sheep, monkey etc.) ${ }^{32}$ express high level of kiss1 mRNA in arcuate nucleus, which supports high level of kiss1 mRNA and neurokinin $B$ in infundibulum of post menopausal women than in premenopausal women. ${ }^{20}$

In the late follicular phase estrogen feedback switches to positive, ultimately induce LH surge for ovulation. Though arcuate Kisspeptin (widely known as KNDY) mediates negative feedback, the positive steroid feedback mediated Kisspeptins are species specific (figure). Apart from Kisspeptin, other KNDY neuron originating from arcuate nucleus do not participate in positive feedback. ${ }^{31,34}$ 


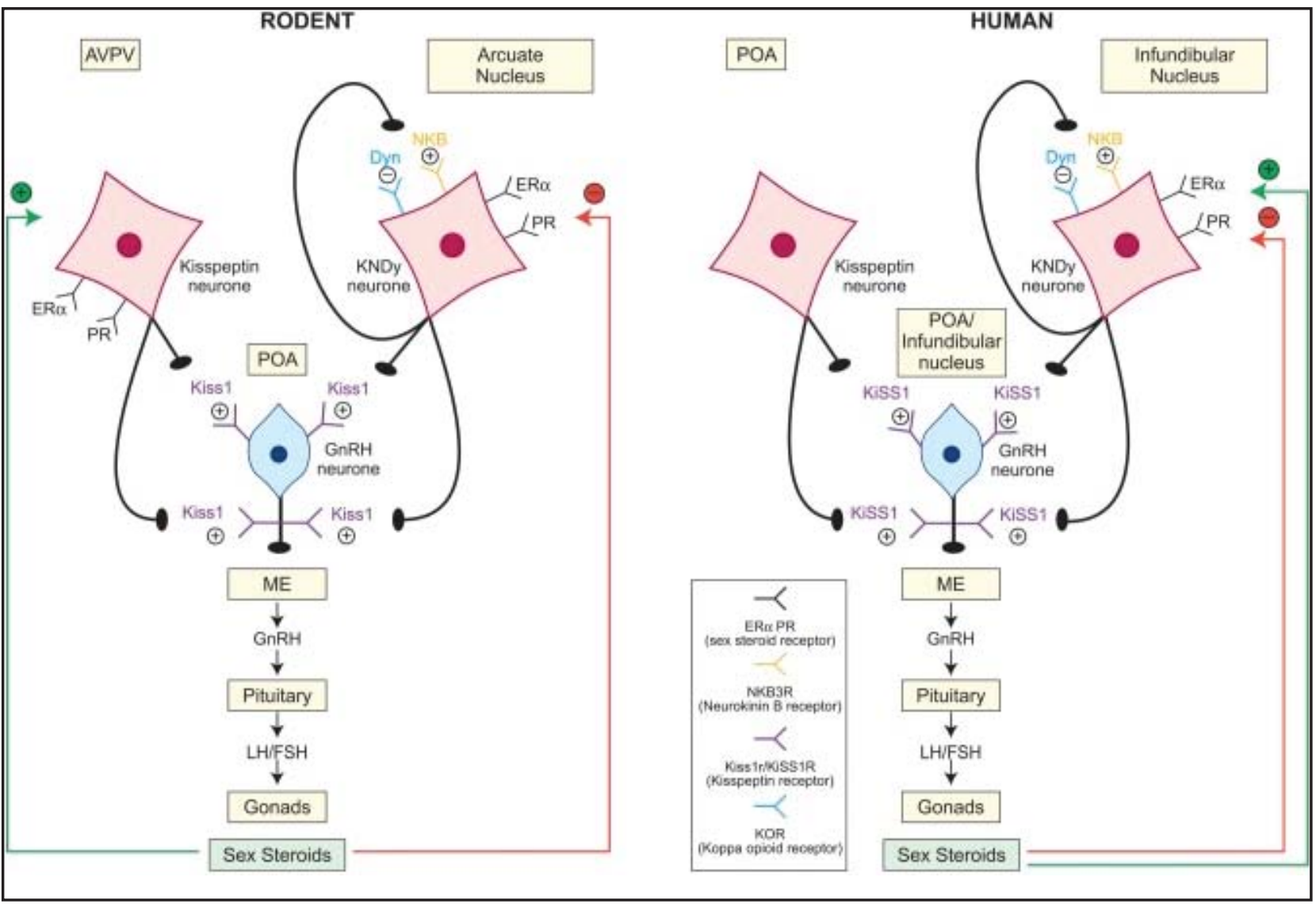

Fig. 1: Illustrative figure of KNDY system and GnRH neurons explain kisspeptin-GnRH pathway in humans and rodents.

Kisspeptin neurons send impulse directly to the GnRH neurons of kisspeptin receptor (Fig. 1). Kisspeptin neurons located in the anteroventral periventricular nucleus (AVPV) and the arcuate nucleus in rodents, and within the preoptic area (POA) and the infundibular nucleus in humans. KNDY neuron regulates kisspeptin pulse through their reciprocal connection via neurokinin B receptor and kappa opioid peptide receptor where neurokinin B acts as stimulatory and dynorphin inhibitory. Negative (red) and positive (green) sex steroid feedback is mediated via distinct kisspeptin populations in rodents, via the AVPV and the arcuate nucleus, respectively. In humans KNDY neurons in the infundibular nucleus relay both negative (red) and positive (green) feedback. The role of the POA kisspeptin population in mediating sex steroid feedback in humans is incompletely explored.

(ME, median eminence; +, stimulatory; -, inhibitory; ER $\alpha$, estrogen receptor alpha; PR, progesterone receptor; Kiss1/KiSS1, kisspeptin; NKB, neurokinin B; dynorphin)

** Slight modified and adapted from: The kisspeptin-GnRH pathway in human reproductive health and disease. 
Clinical Aspects of Kisspeptin in Reproductive Health

Since discovery of inactivating point mutation in gene GPR54 is associated with impaired puberty and idiopathic hypo gonadotrophic hypogonadism in $2003^{8,37}$ it is believed that dysfunction in Kisspeptin neuronal network may be associated with many other clinical disorders. In addition, Teles et al identified activating mutation (Arg 386 Pro) in 2008, which is associated with precocious puberty. ${ }^{38,42}$ Furthermore missense mutation of Kisspeptin has been identified as precocious puberty in three individual cases, which suggests that mutation gene resist in vitro degradation followed by high bio-availability, ultimately causing precocious puberty. ${ }^{39}$

One neuro endocrine disorder is hypothalamic amenorrhea, which is characterized by low GnRH pulse and subsequently declined LH, FSH and failure in follicular development. In this disease, sustained gonadotrophic secretion at normal physiological level was achieved with Kisspeptin inject in subcutaneous twice daily $(6.4 \mathrm{mmol} / \mathrm{kg})$ for 8 weeks. ${ }^{40}$ Though folliculogenesis was not restored in initial studies, the ability of Kisspeptin to increase GnRH secretion and subsequent effect on FSH and LH to restore menstrual cycle will play a major role in the therapeutic approach of Kisspeptin. ${ }^{42}$

Another common disorder in women is PCOS, which is characterized by high level of LH due to neuro endocrine feedback defect and relative high insulin lead to metabolic defect. ${ }^{43} \mathrm{KNDY}$ neurons are believed to be potential regulator of steroid mediated negative feedback. In 2003, Meneilly et al also suggested that GnRH secretion mainly depends on LH level, therefore, reduction of GnRH pulses may restore normal LH secretion. Therefore therapeutic manipulation can be achieved by using Kisspeptin and neurokinin B receptor antagonist or dynorphin agonist through stimulating /inhibitory action of dynorphin. Moreover, ovarian hyper stimulation syndrome (OHSS) in PCO cases can be significantly reduced by kisspeptin. ${ }^{9}$

Kisspeptin may be a good therapeutic option in certain gynecological disorder, for example: endometriosis, uterine fibroid, where partial suppression of gonadotropin secretion is more useful than marked suppression, and significantly reduce side effect of complete suppression. ${ }^{44}$ Data obtained from animal model revealed that kisspeptin antagonist /agonist reduce LH pulse without affecting basal LH secretion (Fig. 2). In contrast, repeated administration of GnRH agonist/antagonist results in marked suppression of gonadotropins, more precisely LH response. Therefore, kisspeptin may be a key player in treatment of reproductive endocrine diseases and In vitro fertilization (IVF). 


\section{REVIEW ARTICLE}
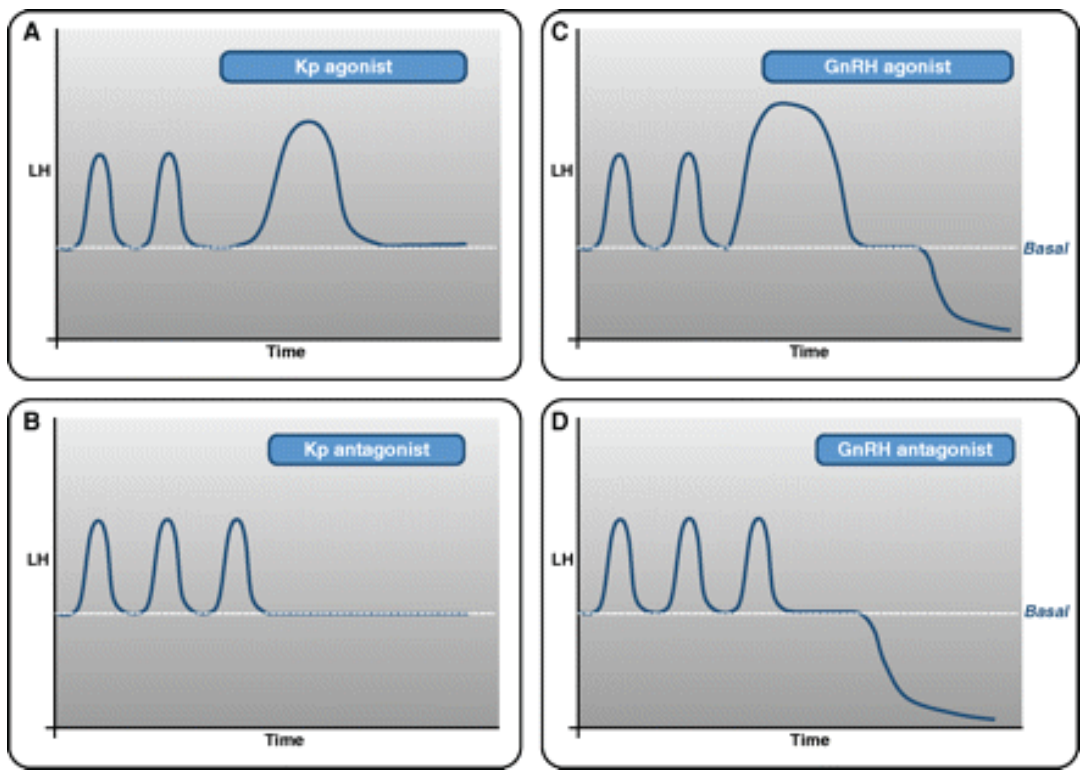

\section{**Fig 2: Schematic figure of tentative LH secretion pattern after continuous administration of kisspeptin agonist (A), antagonist (B), GnRH agonist (C) and GnRH antagonist (D).}

Data obtained from animal model revealed that kisspeptin antagonist /agonist reduce LH pulse without affecting basal LH secretion. In contrast, repeated administration of GnRH agonist/antagonist results marked suppression of gonadotropins, more precisely LH response. Therefore, kisspeptin may be key player in treatment of reproductive endocrine diseases and In vitro fertilization (IVF)

** Adapted from Pinilla L, Aguilar E, Dieguez C, Millar RP, Tena-Sempere M. Review Kisspeptins and reproduction: physiological roles and regulatory mechanisms. Physiol Rev. 2012 Jul; 92(3):1235-316

\section{Conclusion}

In the last couples of years, kisspeptin is considered as key regulator of HPG axis and coordinator of GnRH secretions. Recent understanding on regulation of LH pulse by kisspeptin creates a new opportunity in treatment modalities of reproductive endocrinology and infertility. Now it is believed that consequent effect of complete $\mathrm{GnRH}$ suppression may minimize by ensuring basal LH secretion through kisspeptin analogue. Therefore, it will play a master role in the treatment of future female infertility.

\section{Reference}

1. Belchetz PE, Plant TM, Nakai Y, Keogh EJ, Knobil E. Hypophysial responses to continuous and intermittent delivery of hypopthalamic gonadotropin-releasing hormone. Science. 1978;202:631-33.

2. Kelch RP, Hopwood NJ, Sauder S, Marshall JC.

Evidence for decreased secretion of gonadotropin-releasing hormone in pubertal boys during short-term testosterone treatment. Pediatr Res.

1985;19:112-17.

3. Knobil E, Plant TM, Wildt L, Belchetz PE, Marshall G. Control of the rhesus monkey menstrual cycle: permissive role of hypothalamic gonadotropin-releasing hormone. Science. 1980;207:1371-73.

4. Santoro N, Filicori M, Crowley WF Jr.

Hypogonadotropic disorders in men and women: diagnosis and therapy with pulsatile gonadotropin-releasing hormone. Endocr Rev. 
1986;7:11-23.

5. Conn PM, Freeman ME, Fink G, Conn PM. Totowa. Neuroendocrine regulation of pituitary function: general principles. Neuroendocrinology in Physiology and Medicine. NJ: Humana. 2000. p. 107-134.

6. Schwartz NB, Conn PM, Freeman ME. Totowa. Neuroendocrine regulation of reproductive cyclicity. Neuroendocrinology in Physiology and Medicine, NJ: Humana. 2000. p. 135-146.

7. Tena-Sempere M, Huhtaniemi I, Fauser. Gonadotropins and gonadotropin receptors. In: Reproductive Medicine: Molecular, Cellular and Genetic Fundamentals, BCJM. New York: Parthenon, 2003. p. 225-244.

8. Seminara SB, Messager S, Chatzidaki EE, Thresher RR, Acierno JS Jr, Shagoury JK. The GPR54 gene as a regulator of puberty. N Engl J Med. 2003; Oct 23;349(17):1614-27.

9. Skorupskaite K, Jyothis T George, Richard A Anderson. The kisspeptin-GnRH pathway in human reproductive health and disease. Hum Reprod Update. Jul 2014;20(4): 485-500.

10. Lee JH, Miele ME, Hicks DJ, Phillips KK, Trent JM, Weissman BE, et al. KiSS-1, a novel human malignant melanoma metastasis-suppressor gene. J Natl Cancer Inst. 1996 Dec 4; 88(23):1731-7.

11. Muir AI, Chamberlain L, Elshourbagy NA, Michalovich D, Moore DJ, Calamari A. AXOR12, a novel human $\mathrm{G}$ protein-coupled receptor, activated by the peptide KiSS-1. J Biol Chem. 2001. 276: 28969-75. 12. Ohtaki T, Shintani Y, Honda S, Matsumoto H, Hori A, Kanehashi K. Metastasis suppressor gene KiSS-1 encodes peptide ligand of a G-protein-coupled receptor. Nature. 2001;May 31;411(6837):613-7.

13. Kotani M, Detheux M, Vandenbogaerde A, Communi D, Vanderwinden JM, Le Poul E, et al. The metastasis suppressor gene KiSS-1 encodes kisspeptins, the natural ligands of the orphan $\mathrm{G}$ protein-coupled receptor GPR54. J Biol Chem. 2001 Sep 14; 276(37):34631-6.

14. Pinilla L, Aguilar E, Dieguez C, Millar RP,

Tena-Sempere M. Review Kisspeptins and reproduction: physiological roles and regulatory mechanisms. Physiol Rev. 2012 Jul; 92(3):1235-316.

15. West A, Vojta PJ, Welch DR, Weissman BE. Chromosome localization and genomic structure of the KiSS-1 metastasis suppressor gene (KISS1).Genomics. 1998 Nov 15; 54(1):145-8.

16. Liu X, Lee K, Herbison AE. Kisspeptin excites gonadotropin-releasing hormone neurons through a phospholipase C/calcium-dependent pathway regulating multiple ion channels. Endocrinology. 2008

Sep;149(9):4605-14.

17. Constantin S, Caligioni CS, Stojilkovic S, Wray S. Kisspeptin-10 facilitates a plasma membrane-driven calcium oscillator in gonadotropin-releasing hormone-1 neurons. Endocrinology. 2009 Mar;150(3):1400-12. 18. Clements MK, McDonald TP, Wang R, Xie G, O'Dowd BF, George SR, et al. FMRFamide-related neuropeptides are agonists of the orphan G-protein-coupled receptor GPR54. Biochem Biophys Res Commun. 2001 Jun 29;284(5):1189-93. 19. Brailoiu GC, Dun SL, Ohsawa M, Yin D, Yang J, Chang JK, et al. KiSS-1 expression and metastin-like immunoreactivity in the rat brain. J Comp Neurol. 2005;481:314-329.

20. Rometo AM, Krajewski SJ, Voytko ML, Rance NE. Hypertrophy and increased kisspeptin gene expression in the hypothalamic infundibular nucleus of postmenopausal women and ovariectomized monkeys. J Clin Endocrinol Metab. 2007 Jul;92(7):2744-50. 21. Hrabovszky E, Ciofi P, Vida B, Horvath MC, Keller $\mathrm{E}$, Caraty A. The kisspeptin system of the human hypothalamus: sexual dimorphism and relationship with gonadotropin-releasing hormone and neurokinin B neurons. Eur J Neurosci. 2010 Jun; 31(11):1984-98. 22. Ciofi P, Leroy D, Tramu G. Sexual dimorphism in the organization of the rat hypothalamic infundibular area. Neuroscience. 2006 Sep 15;141(4):1731-45. 23. Krajewski SJ, Anderson MJ, Iles-Shih L, Chen KJ, Urbanski HF, Rance NE. J Comp Neurol. 2005 Aug 29;489(3):372-86.

24. Ciofi P, Leroy D, Tramu G. Sexual dimorphism in the organization of the rat hypothalamic infundibular area. Morphologic evidence that neurokinin B modulates gonadotropin-releasing hormone secretion via neurokinin 3 receptors in the rat median eminence. Neuroscience. 2006 Sep 15;141(4):1731-45.

25. Ramaswamy S, Guerriero KA, Gibbs RB, Plant TM. Structural interactions between kisspeptin and GnRH neurons in the mediobasal hypothalamus of the male rhesus monkey (Macaca mulatta) as revealed by double immunofluorescence and confocal microscopy.

Endocrinology. 2008 Sep;149(9):4387-95.

26. Pompolo S, Pereira A, Scott CJ, Fujiyma F, Clarke IJ. Evidence for estrogenic regulation of gonadotropin-releasing hormone neurons by glutamatergic neurons in the ewe brain: An immuno histo chemical study using an antibody against vesicular glutamate transporter-2. J Comp Neurol. 2003 Oct 6;465(1):136-44.

27. Oakley AE, Clifton DK, Steiner RA. Review Kisspeptin signaling in the brain. Endocr Rev. 2009 Oct;30(6):713-43.

28. Kristen A. Ruka, Laura L. Burger, and Suzanne M. Moenter. Regulation of arcuate neurons co expressing kisspeptin, neurokimin B, and dynorphinby modulators of neurokinin3 and $\mathrm{k}$ opiod receptors in adult male mice. Endocrinology. August 2013; 154(8): 2761-71. 


\section{ORIGINAL ARTICLE}

29. Robert L. Goodman, Stanley M. Hileman, Casey C Nestor, Katrina L. Porter, John M. Connors, et al. Kisspeptin, neurokinin B, and dynorphin act in the arcuate nucleus to control activity of the GnRH Pulse Generator in Ewes. Endocrinology. Nov 2013; 154 (11): 4259-69.

30. Foradori CD, Coolen LM, Fitzgerald ME, Skinner

DC, Goodman RL, Lehman MN. Colocalization of progesterone receptors in parvicellular dynorphin neurons of the ovine preoptic area and hypothalamus. Endocrinology. 2002 Nov;143(11):4366-74.

31. Burke MC, Letts PA, Krajewski SJ, Rance NE. Coexpression of dynorphin and neurokinin $B$ immunoreactivity in the rat hypothalamus: Morphologic evidence of interrelated function within the arcuate nucleus. J Comp Neurol. 2006 Oct 10; 498(5):712-26. 32. Lehman MN, Coolen LM, Goodman RL. Review Mini review: kisspeptin/neurokinin B/dynorphin (KNDy) cells of the arcuate nucleus: a central node in the control of gonadotropin-releasing hormone secretion. Endocrinology. 2010 Aug;151(8):3479-89.

33. Clarkson J, Herbison AE. Postnatal development of kisspeptin neurons in mouse hypothalamus; sexual dimorphism and projections to gonadotropin-releasing hormone neurons. Endocrinology. 2006

Dec;147(12):5817-25.

34. Navarro VM, Gottsch ML, Chavkin C, Okamura H, Clifton DK, Steiner RA. Regulation of gonadotropin-releasing hormone secretion by kisspeptin /dynorphin /neurokinin B neurons in the arcuate nucleus of the mouse. J Neurosci. 2009 Sep 23; 29(38):11859-66. 35. Shaw ND, Histed SN, Srouji SS, Yang J, Lee H, Hall JE. Estrogen negative feedback on gonadotropin secretion: evidence for a direct pituitary effect in women. J Clin Endocrinol Metab. 2010 Apr;95(4):1955-61. 36. Cheng G, Coolen LM, Padmanabhan V, Goodman RL, Lehman MN. The kisspeptin/neurokinin B/dynorphin (KNDy) cell population of the arcuate nucleus: sex differences and effects of prenatal testosterone in sheep. Endocrinology. 2010 Jan; 151(1):301-11

37. De Roux N, Genin E, Carel JC, Matsuda F, Chaussain JL, Milgrom E. Hypogonadotropic hypogonadism due to loss of function of the KiSS1-derived peptide receptor GPR54. Proc Natl Acad Sci USA. 2003;100:10972-76.

38. Teles MG, Bianco SD, Brito VN, Trarbach EB, Kuohung W, Xu S, Seminara SB, Mendonca BB, Kaiser UB, Latronico AC.A GPR54-activating mutation in a patient with central precocious puberty. N Engl J Med. 2008 Feb 14;358(7):709-15.

39. Silveira LG, Noel SD, Silveira-Neto AP, Abreu AP, Brito VN, Santos MG, et al. Mutation of kiss1 gene in disorder of puberty. J Clin Endocrinol Metab. 2010 May; 95(5):2276-80.

40. Shahab M, Mastronardi C, Seminara SB, Crowley WF, Ojeda SR, Plant TM. Increased hypothalamic GPR54 signaling: a potential mechanism for initiation of puberty in primates. Proc Natl Acad Sci U S A. 2005 Feb 8;102(6):2129-34.

41. Jayasena CN, Nijher GM, Abbara A, Murphy KG, Lim A, Patel D. Twice-weekly administration of kisspeptin-54 for 8 weeks stimulates release of reproductive hormones in women with hypothalamic amenorrhea. Clin Pharmacol Ther. 2010 Dec;88(6):840-7. 42. Jayasena CN, Abbara A, Comninos AN, Ratnasabapathy R, Veldhuis JD, Nijher GK, et al. Kissppeptin-54 administration stimulates pulsatile luteinising hormone secretion in women with hypothalamic amenorrhea. Hum Reprod. 2013a Supplement 1: European Society of Human Reproduction and Embryology 29th Annual Meeting, London, Abstract O-268.

43. Dumesic DA1, Abbott DH, Padmanabhan V. Polycystic ovary syndrome and its developmental origins. Rev Endocr Metab Disord. 2007 Jun;8(2):127-41. 44. Chabbert-Buffet N, Meduri G, Bouchard P, Spitz IM. Review Selective progesterone receptor modulators and progesterone antagonists: mechanisms of action and clinical applications. Hum Reprod Update. 2005 May-Jun; 11(3):293-307. 